\title{
SURVEI ARKEOLOGIS \\ DI KAWASAN HALMAHERA BAGIAN TENGAH
}

\author{
Archaeological Survey in the Central Halmahera Region
}

\author{
Marlon Ririmasse \\ Balai Arkeologi Ambon \\ J1. Namalatu-Latuhalat Ambon 97118 \\ Email: ririmasse@yahoo.com
}

Naskah diterima: 25-01-2013; direvisi: 05-03-2013; disetujui: 10-05-2013

\begin{abstract}
Halmahera is one main island in the northeast region of Wallacea. Having a uniquely environmental profile, Halmahera also serves as a home for a long cultural historical process of this region. Including for archaeological studies. Numbers of preliminary studies have been conducted to understand the dynamic of region's culture in the past. Unfortunately, the quantity and the depth of these studies have not equivalent to the colossal potential of Halmahera's culture history. This research is a part of the efforts to contribute in completing our knowledge on the dynamics of culture history in Halmahera. Focus of this research is to identify the archaeological potential in the geographic area of Central Halmahera. The opening of the large scale nickel mines in this region which is potentially threaten the preservation of the cultural heritage is the main consideration in chosing the research locus. Prelimenary survey has been adopted as an approach in this research. This study found that the region of Central Halmahera is a high potentially area for archaeological research according to the large coverage of the karst area in this region. Rescue and preservation action of sites in the mining area is absolutely necessary in order to maintaining the existence of all cultural heritage in the region.
\end{abstract}

Keywords: Archaeology, Central Halmahera, Karst Region

\begin{abstract}
Abstrak
Halmahera merupakan salah satu daratan utama di timur laut kawasan Wallasea. Tidak hanya memiliki profil lingkungan yang khas, Halmahera juga merupakan rumah bagi proses panjang sejarah budaya kawasan. Termasuk bagi studi arkeologis. Berbagai kajian awal telah dilakukan untuk memahami dinamika budaya masa lalu di wilayah ini. Meski demikian kuantitas dan kedalamannya kiranya belum berbanding lurus dengan potensi raya sejarah budaya Halmahera sebagai sebuah kawasan. Kajian ini merupakan bagian dari upaya dalam berkontribusi melengkapi pengetahuan terkait dinamika sejarah budaya di wilayah Halmahera. Fokus penelitian diarahkan untuk menemukan segenap potensi arkeologis dalam lingkup geografis Halmahera Bagian Tengah. Pembukaan tambang nikel berskala besar di wilayah ini yang mengancam kelestarian warisan budaya menjadi salah satu pertimbangan utama dalam penentuan lokus. Survei penjajakan diadopsi sebagai metode dalam kajian ini. Hasil penelitian menemukan bahwa wilayah Halmahera Tengah memiliki potensi tinggi secara arkeologis mengacu pada bentang luas kawasan karst yang potensial sebagai hunian masa lalu dan segenap jejak tradisi yang masih melekat dalam keseharian masyarakat. Tindakan penyelamatan dan pelestarian atas situs-situs dalam pertambangan nikel mutlak diperlukan untuk menjaga eksistensi segenap warisan budaya dalam kawasan.
\end{abstract}

Kata Kunci: Arkeologi, Halmahera Tengah, Kawasan Karst 


\section{PENDAHULUAN}

Himpunan mobil pengangkut berwarna putih rapih berjejer di tepi jalan. Model dan mereknya menunjukan jenis yang tidak umum. Berbeda dengan ragam kendaraan yang ditemui sepanjang jalan tadi. Di samping kendaraan, berdiri orangorang berseragam proyek dengan mantel berwarna terang dan helm pelindung kepala. "Itu mobil perusahaan", Kata Amin, sopir yang mengantar kami. "Sebentar lagi kit akan masuk kawasan perusahaan", lanjutnya. Ketika mobil yang kami tumpangi melintas, sempat terbaca tulisan di pintu mobil-mobi putih tadi: Weda Bay Nickel.

Kurang dari setengah jam kami mulai memasuki kawasan milik perusahaan seperti kata sang sopir. Melewati pos penjagaan, nuansa berbeda langsung terasa. Jalan yang lebih lebar, pembatas jalan, tiang-tiang lampu penerangan yang berdiri kokoh, serta warna-warni papan penunjuk dan peringatan dalam dua bahasa. Truk-truk besar lalu lalang dengan muatan penuh. Sempat pula kam melewati air strip, yang menjadi landa pacu bagi pesawat-pesawat perusahaan. "D bawah itu namanya Tanjung Ulie. Basis bag aktivitas perusahaan Weda Bay Nickel di sini. Dan masih akan terus dikembangkan", tutu Amin menunjuk ke pesisir. Dari ketinggian terlihat jejeran rapih bangunan sepanjang kawasan pantai yang luas. Lengkap dengan dermaga besar pelabuhan perusahaan. Sejauh yang dapat diamati, wilayah ini jelas akan menjadi kawasan pertambangan besar.

Weda Bay Nickel adalah proyek pertambangan nikel dan kobalt yang berad di pesisir selatan wilayah Halmahera Bagian Tengah. Beberapa rujukan pustaka menyebutkan, inisiasi aktifitas perusahaan telah dimulai sejak tahun 1996 melalui penyelidikan awal untuk mengidentifikasi potensi nikel dan mengembangkannya secara ekonomis. Total cadangan sumberdaya nike di wilayah ini diperkirakan mencapai 345 juta ton kering dan merupakan salah satu cadangan nikel laterit terbesar di dunia yang belun dikembangkan. Nilai cadangan sumber daya ini dperkirakan dapat mendukung operasional masa depan setidaknya hingga 50 tahun mendatang. Potensi ini dipastikan akan terus bertumbuh seiring ditemukannya sumbersumber cadangan baru dalam kawasan Rencananya selain ekplorasi dan eksploitasi sumberdaya nikel, pengembangan juga akan meliputi pembangunan pusat pengolahan. Keseluruhan aktivitas ini mengacu pada kontrak kerja, akan mencakup kawasan seluas 54,874 ha.

Dengan lingkup wilayah kerja yang sedemikian luas, dampak aktivitas pertambangan ini tentu kompleks. Aspekaspek yang terkena imbas setidaknya meliputi dampak lingkungan, dampak sosia dampak budaya serta dampak kesehatan. Ekses aktivitas pertambangan terutama terkait dengan alih fungsi lahan yang semula melekat pada fungsi natural penyangga alam dan fungsi sosial, ekonomi serta kultural masyarakat setempat menjadi fungsi industri yang pada dasarnya bersifat merusak. Segenap fungsi otentik lahan yang sebelumnya ada akan berganti dan membawa ekses bagi lingkungan, budaya dan manusia. Terkait dengan implikasi aktivitas tambang secara sosial-kultural, maka dampak alih fungsi lahan akan sangat dirasakan oleh penduduk setempat dan komunitas-komunitas tradisional yang habitasinya berada dalam wilayah kontrak karya perusahaan. Analisis AMDAL merupakan salah satu wahana untuk meminimalisir dampak negatif alih fungsi lahan serta mendorong terciptanya skema terbaik pengelolaan kawasan dalam kerangka pelestarian yang berkelanjutan. Sumbersumber di media menyebutkan persyaratan AMDAL telah dipenuhi oleh Weda Bay Nike sejak tahun 2009.

$$
\text { Salah satu aspek yang kiranya }
$$
sentral dalam kerangka AMDAL adalah pengelolaan aspek budaya dalam hal ini meliputi dampak aktivitas pertambangan bagi Sumber Daya Budaya yang ada dalam kawasan pertambangan. Termasuk dalam konteks ini adalah segenap sumber daya dan potensi arkeologi yang berada dalam wilayah kontrak karya Weda Bay Nikel. Sebagaimana halnya hutan, pemukiman dan segenap ruang aktivitas penduduk yang akan beralih fungsi, segenap warisan budaya masyarakat lokal dan segenap warisan budaya masyarakat lokal dan
situs-situs potensial untuk studi arkeologi dan sejarah budaya kiranya akan terkena ekses serupa. Kemungkinan terburuk tentu saja melekat pada kenyataan bahwa situs-situs ini akan dihancurkan dan hilang selamanya. Suatu kondisi yang tentu disayangkan menimbang kemungkinan pentingnya peran Halmahera dalam sejarah budaya di Wallasea dan Asia-Pasifik.

Situasi ini menarik perhatian banyak pemerhati studi sejarah budaya dan arkeologi di wilayah Maluku Utara.Salah seorang rekan arkeolog dan akademisi kemudian rekan arkeolog dan akademisi kemudian menginformasikan kondisi dimaksud saat di Ternate akhir tahun 2011. Melalui diskusi dan pertimbangan bersama, disepakati perlunya dilakukan sesegera mungkin dilakukan tinjauan atas situs-situs potensial yang berada dalam kawasan atau di luar kawasan kontrak karya namun dapat terkena imbas aktivitas penambangan. Lima bulan setelah pertemuan dimaksud survei arkeologis kemudian dilaksanakan dengan tujuan memetakan segenap potensi sumber daya arkeologis yang ada dalam lingkup kawasan Weda Bay Nikel dan sekitarnya serta meluas ke wilayah Halmahera tengah secara umum.

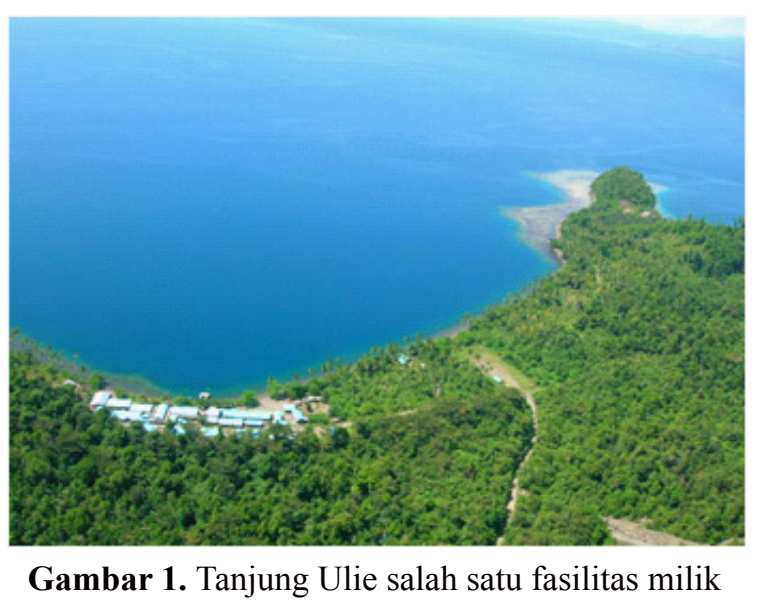
Weda Bay Nickel

(Sumber: http://fr.wikipedia.org/wiki/Weda)
Keputusan ini dilandasi oleh kenyataan bahwa peran Halmahera dalam kerangka studi arkeologis kawasan Asia Tenggara dan Pasifik kiranya sangat sentral. Ragam studi arkeologis yang telah dilakukan sebelumnya menunjukan bukti-bukti budaya masa lalu hingga masa akhir Pleistosen. Demikian halnya peran dinamis wilayah in sebagai bagian dari koridor pelayaran bagi proses migrasi manusia menjelang akhir masa prasejarah dari Asia Timur menuju Pasifik. Pada masa awal sejarah, Halmaher merupakan rumah bagi komoditi eksotik cengkeh yang mendorong wilayah ini masuk dalam jaringan perdagangan lintas kawasan. Seiring kemunculan kerajaan-kerajaan besar di Maluku Utara, Halmahera menjadi ruang kontestasi politik dan ideologi hingga kedatangan orang-orang Eropa. Berpijak pada kondisi dimaksud maka studi sejarah budaya dan arkeologis menjadi wahana kunci dalam menjelaskan segenap proses dinamis wilayah ini di masa lalu. Tinjauan arkeologis atas wilayah Halmahera bagian tengah hingga saat ini masih minimal. Dalam kaitan denga pembukaan aktivitas penambangan nikel $\mathrm{d} i$ wilayah ini, maka kajian untuk merekam segenap potensi sumber daya arkeologis dalam kawasan menjadi lebih mendesak. Survei arkeologis yang dilaksanakan oleh Balai Arkeologi Ambon ini merupakan salah satu wahana untuk menjawab kondis dimaksud. Bercermin pada situasi ini maka permasalahan yang menjadi basis penelitian ini kiranya melekat pada beberapa pertanyaan berikut:

1. Bagaimanakah potensi dan karakter arkeologi prasejarah di kawasan Weda dan sekitarnya?

2. Adakah situs-situs prasejarah potensial yang terancam oleh aktifitas penambangan Weda Bay Nickel?

Mengacu pada pertanyaan di atas maka penelitian ini bersifat eksploratif untuk mendata segenap potensi arkeologi prasejarah di pesisir Halmahera Bagian Tengah Khususnya titik-titik yang diindikasikan terkait dengan hunian awal manusia masa 
Plestosen dan lokus yang mewakili peran wilayah ini dalam proses migrasi penutur bahasa Austronesia. Kawasan karst di wilayah pesisir akan menjadi perhatian dengan pengamatan yang akan ditujukan pada lokus gua, ceruk dan situs terbuka. Penelusuran juga akan dilakukan di daerah aliran sunga yang dilewati. Terkait rencana ekplorasi wilayah ini sebagai daerah penambangan nikel mulai tahun 2013, maka penelitian ini juga diarahkan untuk mendata dan memberikan rujukan penyelamatan sumbe daya arkeologis yang memiliki signifikasi tinggi dalam kawasan.

\section{METODE}

Selaras dengan sifat penelitian yang eksploratif maka survei permukaan diadops sebagai pendekatan utama. Pengamatan dilakukan dengan berjalan kaki untuk meninjau situs dan kawasan lingkungan di sekitar situs. Tujuan pengamatan adalah untuk menentukan titik yang dipandang paling potensial data arkeologisnya Perekaman lokasi situs dilakukan dengan GPS, Kompas, dan Altimeter. Perekaman visual dilakukan dengan foto berskala dan gambar manual terukur. Rekam video bersifat pelengkap. Fokus pengamatan diarahkan untuk menemukan bukti benda budaya di permukaan tanah berupa fragmen gerabah, alat batu atau sisa pengerjaannya, serta struktur megalitik atau struktur bekas pemukiman kuna/negeri lama. Keramik asing dan temuan permukaan dari masa yang lebih kemudian juga direkam. Temuan organik (sisa hewan/cangkang kerang) di anggap penting ketika berasosiasi dengan temuan permukaan lain atau memang dianggap memiliki karakteristik khas. Temuan yang ditemukan dikumpulkan dan disortir menuru jenis temuannya dan lokasi situs. Perekaman juga dilakukan untuk temuan monumental. Selain data temuan lapangan juga direkam benda budaya yang menjadi koleksi desa penduduk dan dianggap memiliki nila sejarah budaya yang memadai. Wawancara dilakukan dengan penduduk atau tokoh adat untuk mendapatkan pengetahuan sejarah ng berhubungan dengan situs-situs yang dikunjungi. Ekskavasi dilakukan dengan membuka kotak uji jika diperlukan.

\section{Halmahera: Tinjauan Wilayah Penelitian} Administratif

Halmahera secara administratif merupakan bagian dari wilayah Propinsi Maluku Utara dengan ibukota, Sofifi. Sebelum tahun 1999, wilayah ini merupakan bagian dari Propinsi Maluku. Kini setelah Maluku Utara menjad propinsi mandiri, Halmahera terbagi dalam tujuh wilayah kabupaten. Adapun lokas penelitian kali ini difokuskan pada wilayah pesisir barat laut-utara Kabupaten Halmahera Tengah.

Tabel 1 Wilayah Administratif Kabupaten di Pulau Halmahera

\begin{tabular}{|l|l|}
\hline Kabupaten & Ibukota \\
\hline Halmahera Barat & Jailolo \\
\hline Halmahera Utara & Tobelo \\
\hline Kepulauan Morotai & Daruba \\
\hline Tidore Kepulauan & Soa Siu \\
\hline Halmahera Timur & Maba \\
\hline Halmahera Tengah & Weda \\
\hline
\end{tabular}

\section{Geografi}

Halmahera sejatinya merupakan pulau terbesar dalam wilayah Kepulauan Maluku, yang dalam hal ini mencakup Propins Maluku dan Maluku Utara. Luas pulau in mencapai 17,400 km2, sedikit lebih besar dari luas Pulau Seram di Bagian Tengah Kepulauan Maluku dengan luas 16,720 $\mathrm{km} 2$. Geografi pulau besar ini berada pada utara garis ekuator dan berbatasan dengan Samudera Pasifik di sebelah utara, Papua di sebelah Timur, Sulawesi di sebelah barat, dan Obi serta Seram di Selatan.

Halmahera merupakan satu di antara 353 buah pulau yang bertaburan di wilayah Kepulauan Maluku Utara. Sebagai pulau terbesar, Halmahera menjadi pulau utama dengan pulau-pulau kecil di sekelilingnya sebagai satelit. Kenampakan fisiografis ditunjukan dengan relief yang besar dan punggung pegunungan yang mencolok, sambung-menyambung dan silih berganti. Titik tertinggi pulau ini ada pada gunung Gamkonora dengan elevasi mencapi 1635 meter di atas permukaan laut. Kondisi ini merupakan dampak dari karakter Maluku Utara sebagai zona pertemuan dua bentang alam yang mencakup sistem bentang alam Sangihe dan sistem bentang alam Ternate serta berbatas dengan cekungan Sulawesi di Barat dan Cekungan Halmahera di Timur. Pada kedua sistem bentang alam ini membentang dua busur pegunungan vulkanik dan non vulkanik yang melalui wilayah barat laut Halmahera.

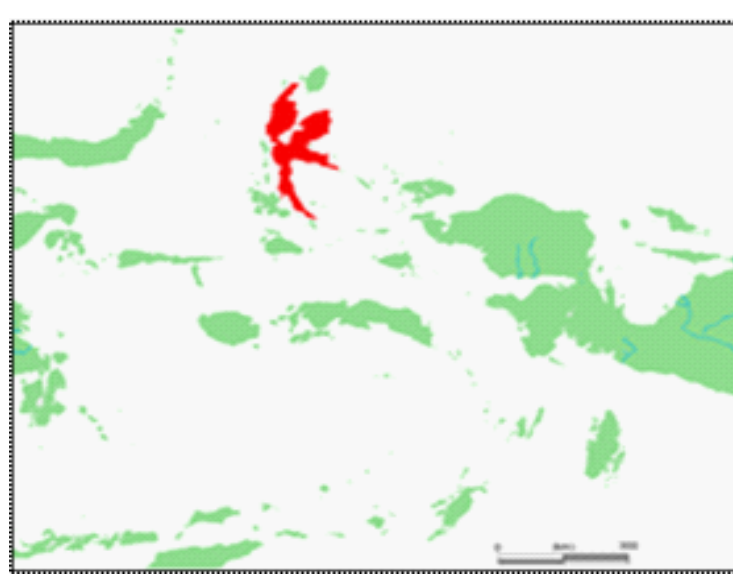

Gambar 2 Keletakan Halmahera dalam Geograf

Kepulauan Maluku dan Kawasan Sekitar (Sumber: www.google.co.id)

Geologi

Sebagai bagian dari wilayah Kepulauan Maluku, Halmahera merupakan bagian dari sebuah kawasan yang secara geologis sangat dinamis. Wilayah ini merupakan titik pertemuan untuk setidaknya tiga lempeng utama dunia yaitu lempeng Eurasia yang mencakup Asia dan sebagian Asia Tenggara Kepulauan; Lempeng Indo-Australia yang mencakup Australia, Aru dan Papua; serta lempeng Pasifik termasuk lempeng Mariana di sebelah timur. Adalah pergerakan di kerak bumi ini yang kemudian pada 15-20 juta tahun lalu mulai melahirkan Kepulauan Maluku. Meski bagian 'kaki-kaki' Halmahera sendiri telah muncul sejak setidaknya 40 juta tahun alu, Halmahera sebagai pulau utuh baru menyatu sekitar dua juta tahun lalu sebagai hasil tumbukan antara lempeng-lempeng tektonik di bagian barat dan timur pulau ini. Bentang lahan pulau Halmahera didominas oleh kawasan perbukitan dan pegunungan. Paparan dataran rendah yang tidak terlalu luas dapat dijumpai di bagian pesisir dan muara sungai. Pada beberapa barisan pegunungan terdapat puncak-puncak gunung api yang sebagian besar masih aktif. Beberapa gunun api yang masih aktif di pulau Halmahera antara lain Dukono, Gamkonora, Ibu, Malupang Watirang dan Mamuja.

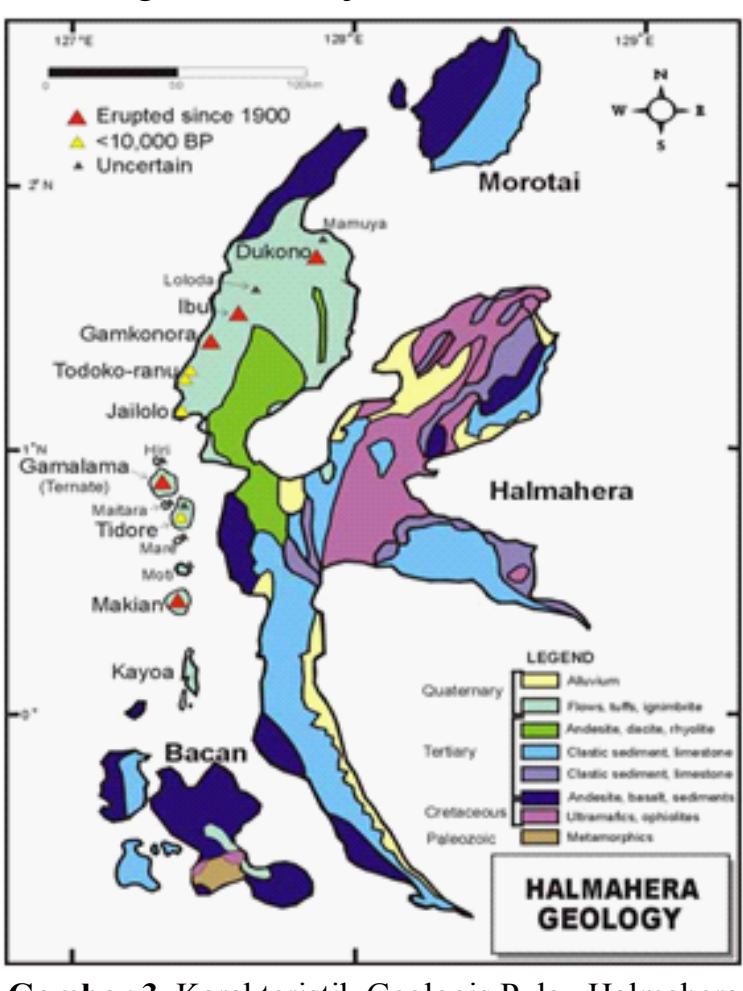

Gambar 3. Karakteristik Geologis Pulau Halmah

(Sumber: http://volcano.oregonstate.edu)

Flora dan Fauna

Halmahera merupakan bagian dari kawasan perantara, Wallacea, yang memisahkan profil hewan dan tumbuhan Asia dan Australia. Kondisi ini tidak lepas dari faktor geologis, dimana Halmahera merupakan bagian dari Kepulauan Maluku yang tidak pernah menyatu dengan daratan besar Asia dan Australia maupun perluasannya. Keberadaan laut dalam di sekeliling kepulauan in sangat mempengaruhi karakter ekologis 
wilayah transisi ini sebagaimana ditunjukan dengan tingkat endemisme yang tinggi yang mencapai $21,8 \%$ dari 385 spesies dan masih terus berlanjut hingga saat ini. Secara umum karakter fauna di Halmahera dan Maluku Utara lebih dekat dengan Papua dibandingkan dengan Sulawesi di sebelah barat. Wilayah ini merupakan habitat luas marsupial, juga diteman di juga ditemukan secara luas di Papua da Australia. Mamalia darat endemis di wilayah ini mencapai 10 jenis sementara mamalia udara mencapai 25 jenis. Kuskus, merupakan salah satu hewan khas yang menjadi penanda dalam kawasan. Spesies Cendrawasih juga ditemukan di pulau Halmahera, namun dengan kenampakan fisikal yang berbeda dengan cendrawasih di Papua dan Kepulauan Aru. Masyarakat Halmahera umumnya menyebut burung indah ini dengan sebutan burung Bidadari. Vegetasi dominan di Halmahera s hutan kayu dan padang rumput dengan sedikit hutan hujan tropis. Hasil hutan yang dapa ditemui saat ini antara lain, sagu, bambu, kayu dan rotan. Cengkeh, Kelapa, pala, jambu mete, coklat, tebu dan karet merupakan hasi lainnya. Tanaman pangan meliputi padi, jagung, aneka umbi hingga kacang-kacangan dan sayur mayur.

\section{Etnografi}

Di Halmahera dan pulau-pulau sekitarnya berkembang dua rumpun bahasa yang berbeda. Yaitu bahasa Austronesia di bagian selatan dan bahasa Non-Austronesia (Papua) di bagian utara. Setidaknya terdapat 7 bahas lokal di Halmahera bagian selatan yang termasuk dalam rumpun bahasa Austronesia dan memiliki persamaan genetik dengan kerabat bahasa Austronesia lainnya di Indonesia Timur. 16 bahasa lokal terdapat di bagian utara Halmahera dan berkerabat dengan bahasa serupa di wilayah Kepala Burung, Papua. Situasi ini menunjukan adanya dua kelompok budaya yang berbeda. Biasanya kelompok-kelompok yang berbed bahasa ini tidak saling memahami bahasa masing-masing. Karena itu muncul bahasa melayu pasar sebagai bahasa perantara atau lingua franca lingua franca dalam kawasan dengan 45\% kosa kata-nya berasal dari bahasa Ternate yang masuk dalam rumpun bahasa nonAustronesia.

Populasi dan Sejarah

Penduduk Halmahera sebagaimana wilayah lain di Kepulauan Maluku (dan Sunda Kecil) memiliki ciri kulit yang lebih gelap dengan rambut keriting sebagaimana halnya penduduk di Papua dan Australia. Ciri ini agaknya menunjukan interaksi dan percampuran antara ras Austromelanesid (atau Austroloid) da para pendatang dari Asta yang datang lebih kemudian. Kelompok-kelompok spesifik ini dapat diamati di Halmahera Utara yang diwakili oleh orang-orang Galela. Mereka berbicara dalam bahasa Papua namun menunjukan ciri fisikal yang khas Indonesia dengan sedikit ciri Melanesia. Penduduk di Halmahera umumnya menerapkan model pertanian berladang dengan komoditi berupa padi, pisang, singkong juga umbi. Penduduk juga mengolah sagu, mencari ikan dan telah lama mengenal teknologi perahu bercadik ganda. Sebelum strategi subsistensi ini dikenal, sebagian besar penduduk Halmahera agaknya hanya mengenal pengolahan sagu dan berburu sebagaimana masih diterapkan oleh Suku Tagutil, komunitas tradisional lainnya di pulau Halmahera.

Sekitar tahun 1500 Masehi, Kepulauan Maluku Utara dibagi menjadi Empat Kerajaan Islam Besar (Moluku Kie Raha) yang berpusat di Ternate, Tidore, Jailolo dan Bacan. Mengacu pada tradisi tutur, keempat kerajaan ini didirikan oleh para putra Jafer Sadek, yang pertama kali menganut Islam melalui para Wali Songo di Pulau Jawa. Raja Bacan adala keturunan dari putra tertua, sementara Ternate adalah keturunan dari putra bungsu. Lepas dari kenyataan bahwa mereka berasal dari nenek moyang yang sama, penduduk Bacan merupakan penutur bahasa Austronesia sementara Ternate, Tidore dan Jailolo adalah penutur bahasa Non-Austronesia (Papua).
Kehadiran bangsa-bangsa Eropa merubah sejarah kawasan ini dan dunia secara mendasar. Portugis tiba di Maluku Utara pada tahun 1512, disusul oleh Spanyol pada 1521, Inggris 1579 dan Belanda pada 1599. Untuk mengambil kendali atas kawasan orang-orang Eropa harus membangun aliansi dengan kerajaan-kerajaan ini. Sumber-sumber sejarah kemudian menunjukan bagaimana Kepulauan Maluku kemudian menjadi ajang adu pengaruh antara dua kerajaan besar yaitu Ternate dan Tidore. Ternate menguasai wilayah sebagian Halmahera bagian tengah dan Halmahera bagian Utara, Seram, Buru, Ambon-Lease dan Banda. Sementara Tidore menguasai sebagian Halmahera Bagian Tengah, Halmahera Bagian Selatan; Daerah Kepala Burung di Papua, dan pulau-pulau kecil di barat laut Papua, termasuk Gebe.

\section{HASIL DAN PEMBAHASAN}

Survei arkeologis di wilayah Halmahera Tengah ini dlaksanakan dengan pengamatan yang mencakup bagian pesisir dan pedalaman mulai dari selatan Kota Weda hingga lepas kawasan Sagea. Hasil pengamatan mendata hampir selusin titik yang dipandang potensial untuk ditinjau secara arkeologis. Adapun karakteristik setiap titik pengamatan yang terekam bervariasi titik pengamatan yang terekam bervariasi
mulai dari situs Gua, Daerah Aliran Sungai, hingga situs bekas pemukiman kuna masa lalu. Deskripsi atas masing-masing titik pengamatan terurai seperti di bawah ini.

\section{Situs Bekas Pemukiman Kuna, Kota, Desa} Nusliko

Kota adalah situs yang disebutkan oleh masyarakat sebagai pemukiman masa lalu dari Desa Nusliko. Situs ini terletak kurang lebih satu kilometer dari desa, sekitar $200 \mathrm{~m}$ dari bibir pantai. Profil situs memiliki karakter yang kurang lebih serupa dengan situs-situs pemukiman kuna di Kepulauan Maluku Bagian Tengah dan Bagian Tenggara yang umum dikenal sebagai negeri lama. Terdapat pagar keliling dari batu bersusun dengan tinggi sekitar satu meter, melintang dari sisi barat ke timur. Topografi situs menaik dar kawasan pantai menuju bukit rendah dengan ciri batu gamping. Karakter lingkungan yang dibatasi daerah rawa di sisi selatan dan bukit di sisi barat inilah yang agaknya dimanfaatkan sebagai wahana alamiah yang memperkua karakter perbentengan pada situs. Luas situs diperkirakan mencapai 100x200 m, dengan dominasi vegetasi kelapa. Temuan yang berhasil diidentifikasi di situs ini selain karakter perbentengan tradisional adalah himpunan fragmen keramik asing yang berasal dari Cina dan Eropa yang menumpuk di salah satu titik situs. Di antara fragmenfragmen ini terdapat beberapa keramik Eropa yang masih menunjukan logo pabrik pembuat bertuliskan Maastricht, sebuah kota di selatan Negeri Belanda yang uniknya dikombinasi dengan aksara Jawa di bawahnya.

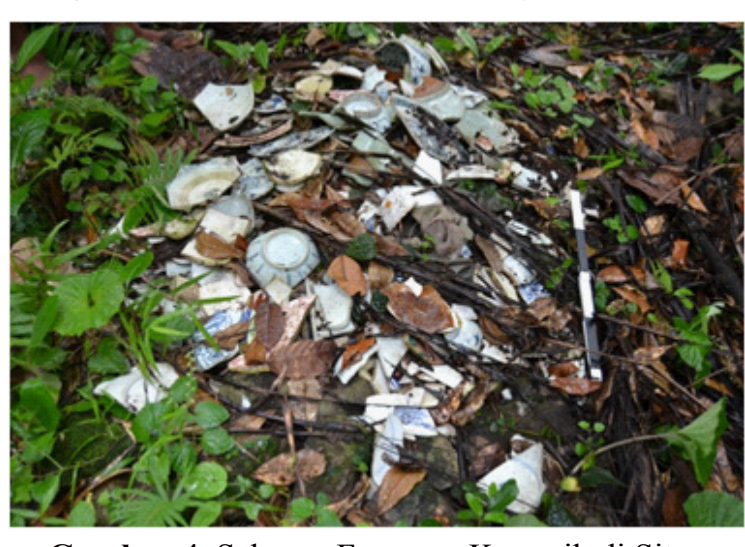

Gambar 4. Sebaran Fragmen Keramik di Si

Bekas Pemukiman Kuna di Nusliko

(Sumber: Dokumen Balai Arkeologi Ambon)

Gua Nusliko

Secara astronomis, situs ini terletak pada N: 00 16 90,3 dan E: 12753 318. Nusliko sejatinya merupakan titik yang dipilih ole tim dalam upaya menemukan kembali Gua Siti Nasifah yang pernah diekskavasi oleh arkeolog Australia, Peter Bellwood pada tahun 1993. Dalam laporannya Bellwood menjelaskan mengenai keberadaan sebuah gua yang berada lima kilometer di selatan kota Weda dengan sebaran temuan kerang di permukaan. Hasil ekskavasi menunjukan adanya lapisan budaya dengan temuan gerabah poles merah yang minimal namun memiliki 
karakter serupa dengan temuan gerabah di situs Tanjung Pinang. Tim melakukan komunikas dengan penduduk dan tokoh masyarakat, namun sayangnya tidak ada satupun warga yang mengetahui keberadaan gua Siti Nasifah yang disebutkan oleh Belwood. Gua yang dikunjungi oleh tim terletak kurang lebih 2 kilometer dari desa pada ketinggian $110 \mathrm{~m}$ di atas permukaan laut. Terletak diperbukitan batu gamping dengan tanjakan terjal namun pendek. Situs ini terletak tepat di tepi jalan yang menghubungkan desa Nosliku dan desa tetangga. Orientasi gua menghadap ke Utara, tepat ke arah laut dengan pemandangan teluk Weda dan kota Weda di Barat Laut Terdapa dua bilik utama, yaitu teras luar yang terbuka dan bilik dalam yang terbagi atas dua ruang. Lebar mulut gua bagian luar adalah $5,80 \mathrm{~m}$ dan lebar pintu bagian dalam adalah $1,70 \mathrm{~m}$ dengan tinggi atap gua mencaai $1,96 \mathrm{~cm}$. Panjang gua hingga titik terdalam adalah 7,60 meter.

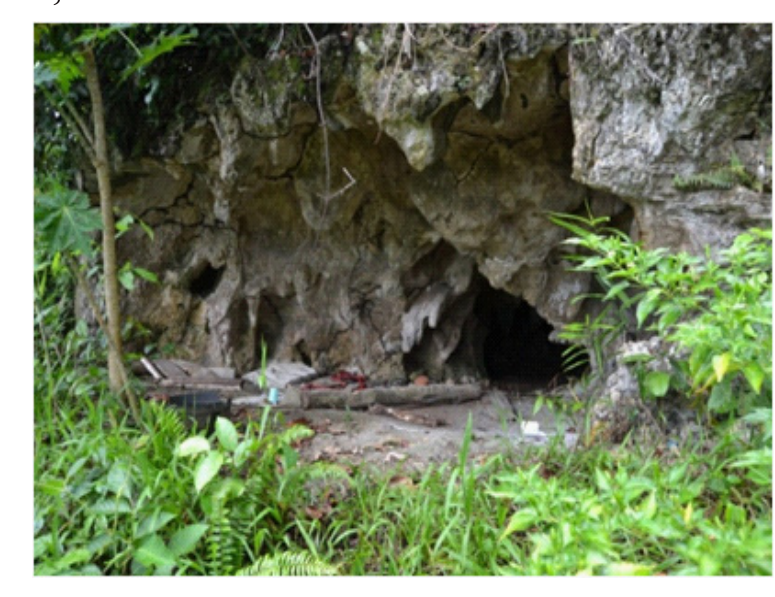

Gambar 5. Gua Nusliko

Sumber: Dokumen Balai Arkeologi Ambon)

Dari hasil pengamatan tim tidak terdapat indikasi temuan gerabah di permukaan lantai gua, namun temuan moluska, tersebar dengan cukup merata, khususnya di bagian teras luar gua. Terdapat juga jejak-jejak pengunaan gua pada masa yang lebih kini yang agaknya dimanfaatkan sebagai tempa peneduh bagi masyarakat desa yang berkebun. Keberadaan gua ini menunjukan potensi gua yang agaknya masih cukup tersebar di pesisi selatan Halmahera. Informasi dari masyarakat juga menyebutkan terdapat gua lain di dalam hutan namun dengan jarak tempuh yang mencapai hampir satu hari.

Jere, Makam Tradisional, Telaga Nusliko Desa Nusliko Kecamatan Weda Selatan Secara astronomis, situs ini terletak pada N: 0017853 dan E: 12752 480. Lokasi makam ini terletak pada daerah muara sebelah barat desa Nusliko, yang oleh penduduk disebut sebagai telaga Nusliko. Untuk mencapai situs kita perlu menyeberang dengan menggunakan ketinting yang disewa dari penduduk setempat. Sudah ada dermaga kecil yang terbuat dari papan di lokasi situs yang agaknya relatif baru dibangun oleh desa. Sebelum memasuki pemakaman, kita akan menemukan rumah kecil yang digunakan untuk meletakan sesaji. Saat diamati masih terlihat aneka sesaji di atas berbagai macam piring yang diletakan diatas para-para yang terlindung oleh hiasan daun kelapa. Untuk mencapai makam, harus melalui tangoa naik dengan tinggi kurang lebih 30 meter. Makam kuna ini terletak di bibir jurang, dengan bentuk bujur sangkar, berupa gundukan tanah yang dipagari dengan fragmen terumbu karang. Dimensi makam sekitar 1,30 x 1,20 m dengan hiasan bendera putih di sekelilingnya.

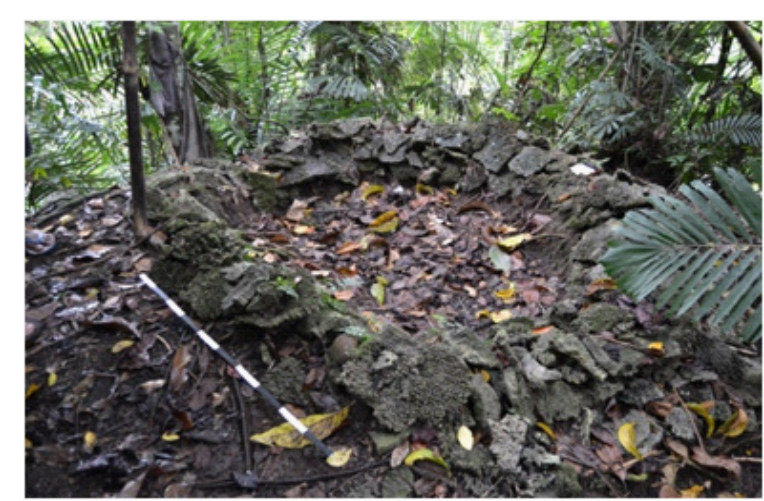

Gambar 6. Jere atau tempat keram di Desa Nusliko

(Sumber: Dokumen Balai Arkeologi Ambon)

\section{Gua Bokimoruru, Sagea}

Gua Bokimoruru adalah Gua Alam yang sudah cukup dikenal. Lokasi ini sejatinya merupakan satu ikon unggulan bagi wisata alam di Kabupaten Halmahera Tengah. Sayangnya, kendala infrastruktur berupa jalan dan sarana transportasi dirasa sangat membatasi akses menuju situs yang menjanjikan ini. Bokimoruru secara administratif termasuk dalam wilayah Desa Sagea Kecamatan Weda Utara. Perjalanan menuju lokasi dari desa ditempuh dengan menggunakan perahu motor tempel selama satu jam melawan arus sungai Sangea menuju daerah hulu. Profil situs ini ditunjukan dengan karakter khas sebagai gua aktif karena masih dilalui oleh aliran sungai. . Pintu gua menghadap barat laut dengan tinggi mencapai kurang lebih 30 meter. Jarak dari mulut gua hingga akhir zona terang kurang lebih 200 meter sebelum masuk ke zona peralihan sepanjang kurang lebih 100 meter. Pengamatan di sekeliling lingkungan situs menunjukan potensi adanya gua kecil dan ceruk peneduh di atas kawasan gua Bokimoruru. Pengamatan atas lingkungan situs hampir tidak menunjukan adanya indikasi temuan arkeologis. Satu-satunya temuan di lokus ini diwakili oleh keberadaan proto kapak penetak di bantaran sungai depan pintu masuk gua.

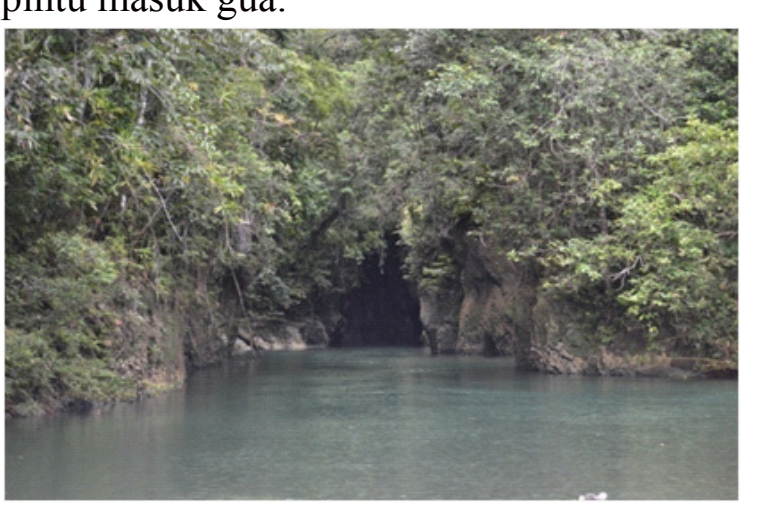

Gambar 7. Gua Bokimoruru di Sagea diamati dari Sungai Sage

(Sumber: Dokumen Balai Arkeologi Ambon)

Gunung Sora 1

Situs Gunung Sora adalah kawasan perbukitan gamping yang terletak di bagian timur laut Desa Gemaf. Situs ini dapat dicapai dengan menggunakan mobil menuju tepian kali Gemaf dilanjutkan dengan berjalan kaki selama hampir 1 jam melalui perkebunan penduduk dan hutan kecil di kaki bukit. Profil bukit ini ditunjukan dengan topografi yang cukup curam dan gugusan dinding batu gamping. Situs Gunung Sora 1 adalah ceruk yang terletak di sisi barat Gunung Sora. Kondisi ceruk lembab dan dengan dimensi yang tidak besar. Hasil pengamatan tidak menunjukan adanya jejak temuan d permukaan ceruk dan sekitar lokasi.

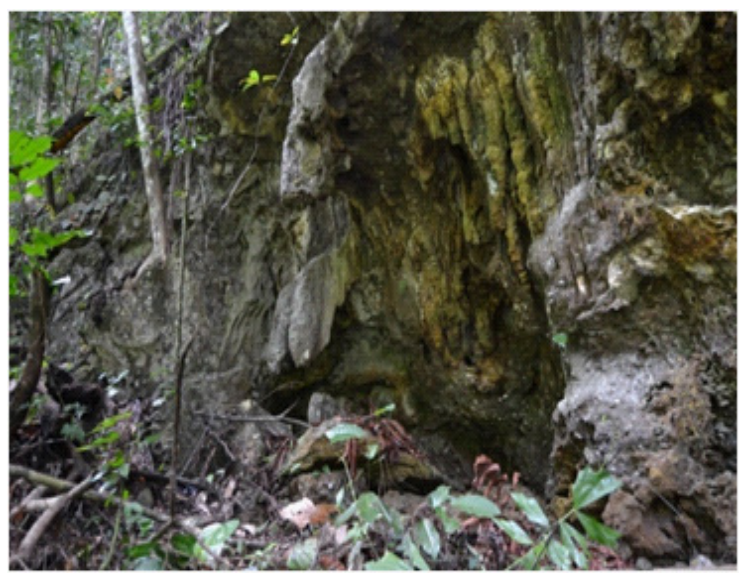

Gambar 8. Ceruk di Situs Gunung Sora 1 (Sumber: Dokumen Balai Arkeologi Ambon)

Gua Sora 2

Situs ini terletak di titik yang lebih tinggi dari Gunung Sora 1. Dapat dicapai dengan menaiki lereng ke arah utara. Gunung Sora 2 adalah gua vertikal dengan 2 pintu masuk, menuju selatan dan menuju barat. Terdapat lorong dalam gua yang cukup panjang dan menembus hingga bagian lain Perbukitan ini. Hasil pengamatan tidak menunjukan adanya tanda-tanda jejak budaya yang jelas terkait dengan kondisi gua yang tidak layak huni akibat topografi curam, lembab dan pencahayaan minimal.

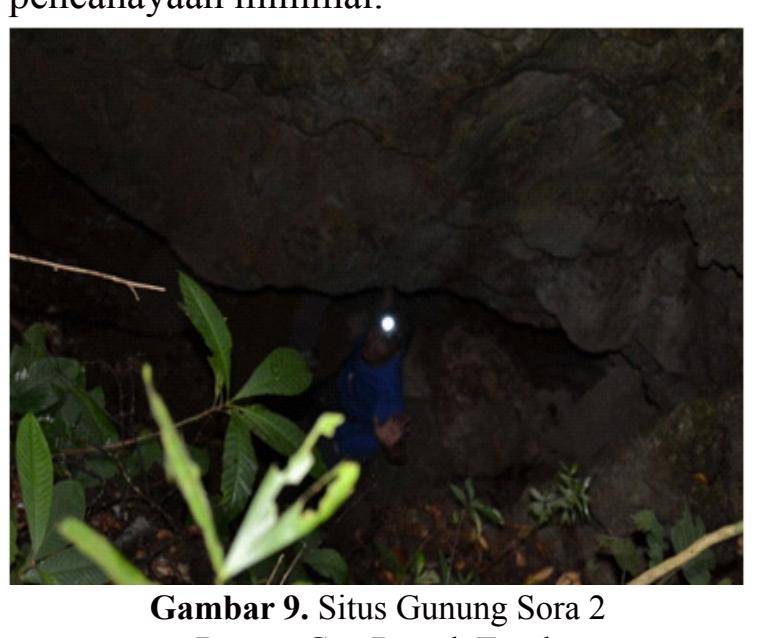

Gambar 9. Situs Gunung Sora

(Sumber: Dokumen Balai Arkeologi Ambon) 
Gua Sora 3

Situs ini adalah yang terbaik yang diamati di kawasan Gua Sora. Gunung Sora 3 adala situs ceruk peneduh yang terletak pada dinding gamping sebelah selatan kawasan. Kondisi ceruk kering dengan sinar matahari yang memadai. Keletakan situs di ketinggian juga memberi ruang aman bagi penghuni. Hasil pengamatan mengidentifikasi temuan berupa moluska dan cranial vertebrata kecil namun tidak ditemukan adanya jejak artefaktual.

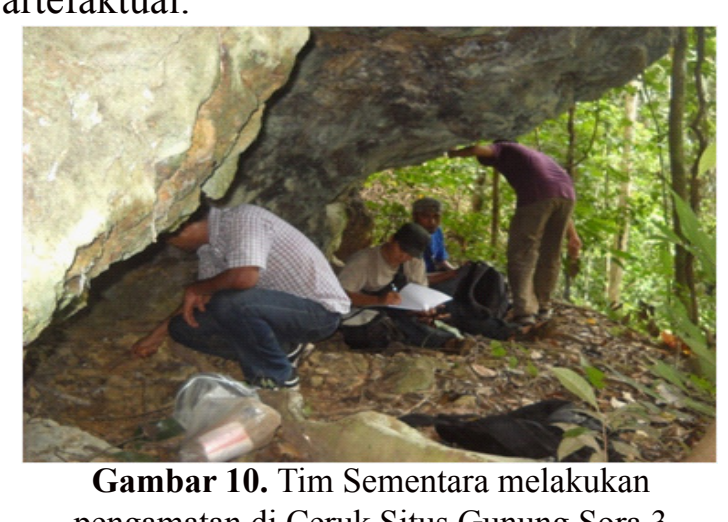

pengamatan di Ceruk Situs Gunung Sora 3

(Sumber: Dokumen Balai Arkeologi Ambon)

Parigi Dua

Ceruk vertikal dan gua yang dilalui sunga kecil di sisi timur Gunung Sora. Pintu masuk pada dinding gua sangat rendah, namun bilik di dalam jauh lebih lapang. Kondisi ceruk dan gua lembab dan basah karena dilalu sungai. Tidak ditemukan adanya indikasi jejak budaya di titik ini.

\section{Kali Gemaf}

Kali Gemaf adalah sungai yang melintasi sisi timur desa Gemaf. Kaya dengan batuan jenis skis,batuan beku dan rijang. Lingkungan sekitar situs ditandai dengan perkebunan penduduk dengan dominasi vegetasi berupa kelapa, pisang, alang-alang, dan bambu. Hasil pengamatan menunjukan sungai ini kaya bahan, namun minim jejak artefaktual. Dua indikasi temuan alat prasejarah adalah sebuah alat serpih dan sebuah serut besar.

Gua Yoli

Situs ini terletak di kawasan perbukitan di utara Desa Gemaf. Dapat dicapai dengan ebih dari satu jam dengan topografi yang menaik. Jalur perjalanan juga melintasi sungai Gemaf. Hasil pengamatan menunjukan situs ini adalah ceruk peneduh dengan kondisi yang layak huni. Terdapa jejak moluska dalam jumlah moderat $d i$ permukaan lantai ceruk. Pencahayaan di ceruk ini baik dan kondisi pan gua pun kering. Lebar pintu depan ceruk adalah $5,40 \mathrm{~m}$ dan tinggi $2,10 \mathrm{~m}$. Terdapat sebuah pintu yang lebih sempit menuju bilik dalam dengan lebar $1,15 \mathrm{~m}$. Hasil pengamatan juga menemukan fragmen gerabah dan indikasi alat batu.

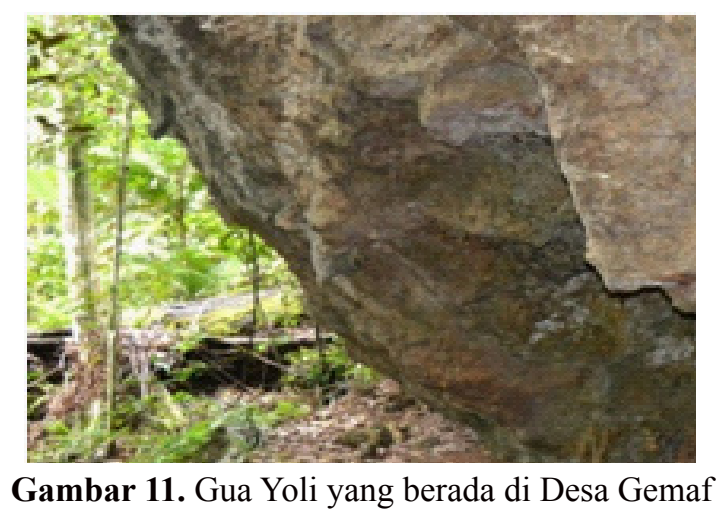

(Sumber: Dokumen Balai Arkeologi Ambo

\section{Halmahera dalam Tinjauan Rekam Sejarah}

\section{Studi Arkeologi di Maluku Utara}

Di Kepulauan Maluku Utara studi atas hunian masa lalu diinisiasi pada tahun 1947 oleh K Schmidt yang mengamati himpunan fragmen gerabah yang ditemukan dekat Sungai Totodoku di Pulau Morotai. Sempat vakum selama beberapa dekade, studi arkeologis untuk menemukan jejak hunian dan aktivitas manusia masa lalu baru kembal dilakukan pada tahun 1978 oleh Pusa Penelitian Arkeologi Nasional dan dipimpin oleh S Soegondho. Survei dilakukan pada himpunan pulau meliputi Kayoa, Makian, Kao, Tobelo, Galela, Jailolo, Sahu, Ternate hingga Tidore. Setidaknya dua ceruk peneduh direkam sebagai lokus yang dipandang memiliki potensi. Masing-masing di Waidoba dan Taneti. Temuan artefaktual diwakili oleh himpunan fragmen gerabah coklat kemerahan dan berhias. Beliung ditemukan di beberapa situs meliputi Doro (Kao), Lolori dan Awer (Sahu), Tanjung Luari (Tobelo) dan Waidoba (Soegondho, 1978; 1980).

W.G Solheim adalah akademisi lain yang juga melakukan studi arkeologis atas titik-titik potensial terkait hunian masa lalu di wilayah Maluku Utara. Dalam kegiatan yang dilakukan antara tahun 1989-1991, jejak artefaktual berupa himpunan fragmen gerabah poles merah dan berhias ditemukan di pulau Kumo-Kumo. Serupa dengan pola hias gerabah yang ditemukan di Siti Nasifah (Halmahera) dan Buwawansi (Gebe) oleh Bellwood.

Kontribusi paling signifikan terkait jejak hunian masa lalu di wilayah Kepulauan Maluku Bagian Utara agaknya disumbangkan oleh aktivitas penelitian kolaborasi IndonesiaAustralia pada antara tahun 1991-1996. Dipimpin oleh Peter Bellwood, empat musim penelitian telah dilakukan dengan perhatian pada beberapa pertanyaan utama meliputi: penanggalan dan sumber pemukiman masa Pleistosen; peran kawasan dalam kajian terkait pemukiman penutur bahasa Austronesia di Pasifik; ihwal interaksi antara penutur Bahasa Austronesia dan Non-Austronesia sejak 4,000 tahun silam; serta sejarah perdagangan rempah dengan Cina, India dan Barat (Bellwood, 2000).

Melalui hasil studi yang dilakukan oleh Bellwood dkk ini, tiga fase budaya setidaknya bisa diamati dari karakteristik yang ditunjukan oleh situs-situs yang telah diekskavasi. Rekam kronologi tertua berasal dari fase pra-keramik dengan penanggalan mencapai 32,500 tahun lalu di Situs Gua Golo, di Pulau Gebe. Beberapa situs dengan penanggalan yang lebih muda teridentifikasi di Daeo 2 di Pulau Morotai (14,000 BP); Um Kapat Papo di Gebe (6,500 BP); dan Siti Nasifah di Weda dengan penanggalan 5,500 tahun silam. Himpunan artefak yang direkam pada fase pre-keramik ini diwakili oleh kapak batu, lancipan tulang, batu tumbuk kenari dan okre. Himpunan kerang dan tulang ikan juga teridentifikasi di beberapa situs di Halmahera dan Morotai. Tulang hewan yang ditemukan meliputi kuskus; walabi (di Gebe

Fase kedua dimulai sekitar 3,500

silam sebagaimana ditandai oleh kemunculan gerabah poles merah serta keberadaan tulang anjing dan babi yang diduga diperkenalkan oleh kelompok migrant berpenutur bahas Austronesia. Karakteristik gerabah yang ditemukan pararel dengan gerabah yang ditemukan di Sulawesi, Filipina, Sabah dan di situs-situs Lapita yang berada di Melanesia Melekat dengan temuan khas di atas adala beliung; alat serpih, lancipan tulang, manikmanik kerang; dan gelang berbahan kerang. Fase yang termuda berasal dari kisaran waktu 2,000 tahun silam dan ditandai dengan kemunculan aneka budaya bendawi baru meliputi manik-manik kaca, perunggu, besi, dan gerabah dengan pola hias yang digunakan secara luas di Indonesia dan Filipina. Di situs Uattamdi di Kayoa, penguburan tempayan ditemukan. Penguburan sekunde dengan bekal hiasan kerang ditemukan di ceruk Tanjung Pinang di Morotai. Fase in kemungkinan berlangsung hingga sekita 1,000 tahun silam atau lebih kemudian $\mathrm{d}$ beberapa tempat yang terisolas (Bellwood, 1998).

Studi atas kawasan utara Wallasea juga dilakukan oleh Tanudirjo (2001) yang meneruskan rangkaian kajian yang telah dilakukan oleh Bellwood. Wilayah yang menjadi perhatian dalam studi ini meliputi Talaud di Sulawesi Utara dan Kepulauan Sula di Maluku Utara. Beberapa situs yang menjadi rujukan antara lain Leang Sarru (Salebabu), Leang Tuo Mana'e (Pulau Karakelong), Leang Arangdangana (Pulau Kabaruan), Leang Tahuna (Pulau Merampit), Ceruk Manaf (Sanana), Waylia (Sanana) dan Gua Fatiba di Sanana. Hasil penelitian menemukan inisiasi okupasi manusia dapa ditarik hingga setidaknya masa Pleistosen Akhir sekitar 30,000 tahun silam. Budaya materi yang berhasil ditemukan melalu ekskavasi menguatkan informasi peran wilayah ini dalam proses migrasi kolosa penutur bahasa Austronesia. Himpunan 
artefak yang teridentifikasi meliputi aneka alat serpih bilah, batu inti, beliung kerang, hiasan kerang, gerabah poles merah dalam asosiasi dengan himpunan tulang hewan dan manusia, serta benda logam. Meski memilik variasi-variasi yang bersifat lokal, ragam temuan artefaktual menunjukan konsistens konfigurasi dengan bukti-bukti budaya semasa dalam kawasan. Suatu kondisi yang menunjukan peran pararel wilayah-wilayah yang ditinjau dalam konteks prasejarah regional.

Catatan dan Prospek Hasil Penelitian terkini dan pengembangan studi kawasan Maluku bagian Utara

Himpunan kajian di atas setidaknya memberikan gambaran dinamika pera Halmahera dan pulau-pulau di Kepulauan Maluku bagian utara pada masa prasejarah. Ragam temuan yang teridentifikasi dengan kemiripan karakter antar satu situs dengan situs lainnya bisa menjadi penanda relasi antar situs dalam kawasan. Beberapa hasi penelitian terkini kiranya merupakan refleks masih luas dan dalamnya dimensi potens kajian prasejarah di wilayah ini. Dalam kaitan rekam penelitian yang telah dilaksanakan dengan hasil survei yang dilakukan kiranya dapat disarikan beberapa hal menyangkut prasejarah kawasan Halmahera Bagian Tengah dan sekitarnya.

Pertama, bahwa wilayah Halmahera bagian tengah merupakan kawasan yang memiliki potensi dalam konteks studi arkeologi prasejarah. Hasil pengamatan terkai karakteristik lingkungan dalam kawasan menunjukan ciri kenampakan lingkungan karst yang meluas dari bagian pesisir hingga pedalaman. Salah satu penanda khas dari kawasan dengan morfologi karst adalah sebaran ragam bentukan gua dan sungai bawah tanah. Menimbang lingkungan gua merupakan salah satu lokus habitasi manusia di masa awal peradaban, maka bentang alamini senantiasa memiliki peran penting bagi studi arkeologi. Hasil survey yang dilakukan oleh Balai Arkeologi Ambon mendata setidaknya empat titik gua yang potensial menjadi hunian manusia masa lalu. Keempat titik gua tersebut masing masing Ceruk Nusliko; Gua Bokimoruru; Ceruk Gunung Sora 3; dan Ceruk Yoli. Indikasi yang ditemukan di Ceruk Nusliko dan ceruk Gunung Sora diwakili oleh temuan fragmen kerang dan tulang yang menandakan okupasi awal manusia dan agaknya berfungsi sebagai habitasi sementara. Di Ceruk Yoli temuan permukaan diwakili oleh keberadaan ala batu, kerang dan fragmen tembikar yang menandakan okupasi manusia dalam waktu yang relatif lama. Ditinjau dari karakteristik temuan permukaan Ceruk Yoli adalah titik dalam cakupan wilayah survei yang memiliki potensi dan nilai penting paling tinggi untuk dikaji dengan lebih mendalam.

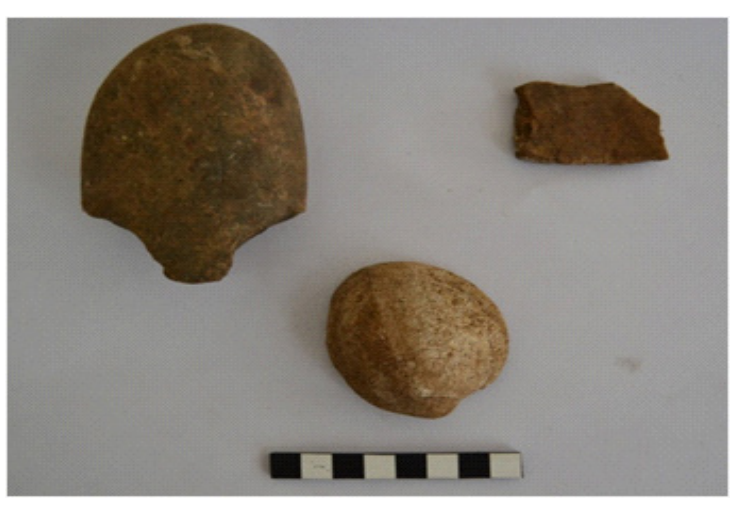

Gambar 12. Temuan permukaan di Gua Yoli

(Sumber: Dokumen Balai Arkeologi Ambon)

Kedua, budaya bendawi yang melekat dengan tradisi setempat dan memiliki tokal. Dari hasil survei yang didata terdapat setidaknya empat titik pengamatan dengan nilai penting paling tinggi. Titik pertama adalah situs pemukiman kuna di Nusliko yang oleh masyarakat setempat disebut sebagai Kota. Model yang ditunjukan oleh situs ini kiranya serupa dengan ragam situs pemukiman kuna yang ditemukan secara luas di Kepulauan Maluku. Karakteristik dari situs-situs in adlah keletakannnya yang berada pada lahan yang relatif tinggi dibanding dengan kawasan di sekitarnya; memiliki akses minimal dan seringkali hanya melalui keliling yang terbuat dari susunan batu dan memberikan ciri defensif pada pemukiman. Titik pengamatan kedua yang memiliki nilai penting bagi masyarakat adalah Jere atau keramat yang terdapat di desa Nusliko dan paralel dengan tempat yang dikeramatkan pagi masyaraka Sebagaimana telah dideskripsikan pada bagian sebelumnya Jere disebutkansebagai makam dari leluhur komunitas setempat dan kini menjadi titik rujukan bagi aktivitas ritual komunal maupun individual.

Ketiga, adalah catatan terkait keletakan beberapa situs yang berada dalam lingkup kawasan Weda Bay Nikel atau diluar wilayah kontrak karya namun dapat terkena dampak aktivitas penambangan. Hasil pengamatan menunjukan himpunan situs yang terekam dalam penelitian ini kiranya dapat dibagi dalam dua kategori mengacu pada keletakan dengan kawasan kontrak karya Weda Bay Nikel serta implikasi terkait aktivitas penambangan yang dilakukan. Pertama, adalah situssitus yang terekam dalam penelitian yang berada dalam lingkupkawasan kontrak karya serta terkena dampak langsung aktivitas penambangan. Survei menujukan dari empat titik potensial secara arkeologis dalam kawasan karst tiga diantaranya masuk dalam kawasan kontrak karya dan terkena dampak langusng aktivitas yaitu: Gua Bokimoruru di Sagea; Gua Gunung Sora 3 dan Ceruk Yoli. Dengan kondisi keempat gua ini potensial untuk terkena imbas langsung aktivitas penambangan yang bersifat destruktif. Pemitakatan atas keempat situs potensial ini mutlak diperlukan untuk melindungi himpunan situs ini dan kawasan perluasannya bagi kepentingan warisan sejarah budaya masyarakat serta studi kepurbakalaan. Kedua, Situs-situs lain yang terekam dalam kegiatan survei kiranya berada di luar kawasan kontrak karya Weda Bay Nikel namun ke depan kiranya dapat saja terkena dampak langsung maupun tidak langsung dari aktivitas penambangan yang dilakukan perusahaan. Pengamatan yang dilakukan pada situs resmi Weda Bay Nikel menyebutkan bahwa proses assessment untuk memetakan dampak aktivitas penambangan bagi warisan budaya telah dilakukan namu belum ditemukan deskripsi rinci terkait situssitus yang termasuk serta penjelasan terkait langkah-langkah yang akan diambil terkait pelestarian situs-situs yang berada dalam lingkup kawasan kontrak karya.

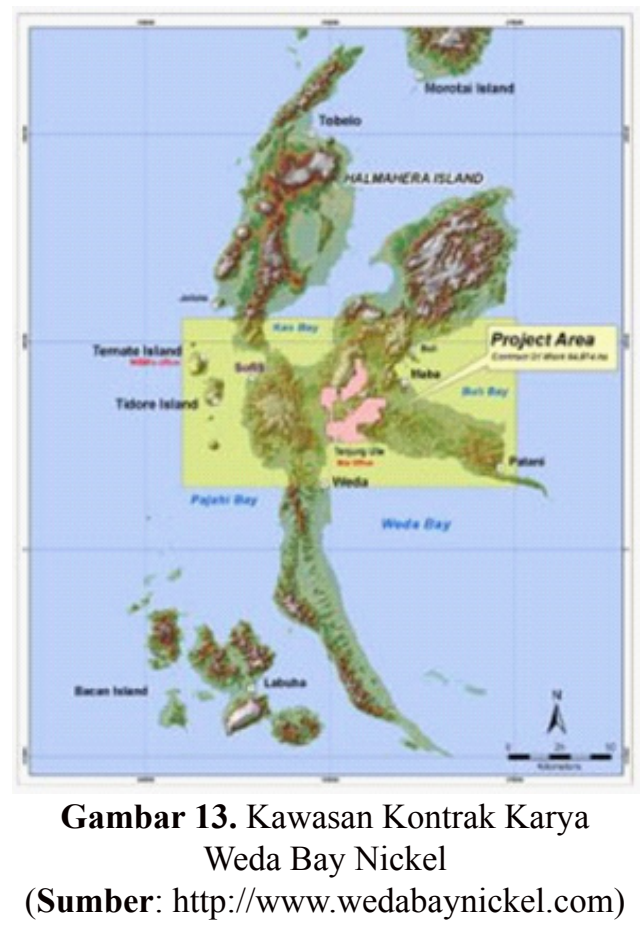

Keempat, bercermin pada penjelasan ketiga aspek sebelumnya kiranya dapat digaga beberapa hal terkait penelitian ke depan untuk kawasan Halmahera Bagian Tengah. Pertama aspek dengan nilai urgensi tertinggi kiranya melekat pada penanganan segenap situs-situs yang berada dalam lingkup wilayah kontra karya Weda Bay Nikel. Meski menuru pihak perusahaan telah dilakukan mitigas terkait warisan budaya yang terkena dampak ktivitas penambangan namun hingga saat ini belum ada kejelasan langkah-1 yang akan diambil terkait penyelamatan dan pelestarian situs-situs dimaksud. Mengacu pada situasi ini makanya kiranya penting untuk segera melaksanakan aktivitas penelitia yang bersifat tindakan penyelamatan untuk merekam segenap data dan karakteristik 
situs secara spesifik. Keempat gua potensial yang disebutkan memiliki indikasi potensi arkeologis sebagai hunian masa lalu kiranya perlu untuk segera dilakukan tindakan ekskavasi penyelamatan guna merekam segenap potensi data sejarah budaya dalam lingkup situs. Aktivitas penelitian dan ekskavasi ini kirannya mendesak sebelum kegiatan operasional eksploitasi dilaksnakan oleh perusahaan. Hasil ekskavasi kiranya akan menentukan arah kebijakan penyelamatan dan pelestarian situs. Hal kedua kiranya menyangkut kebijakan pelestarian dan pengelolaan segenap sumber daya buday yang melekat dengan tradisi dan memiliki nilai penting bagi masyarakat setempat. Keberadaan situs Kota dan Jere Nusliko sejauh ini masih cukup terawatt dan tetap memiliki nilai sakral bagi masyarakat. Hasil diskusi dan wawancara dengan masyarakat menyebutkkan hingga saat ini kedua titik dimaksud belum diregistrasi sebagai bagian dari sumber daya budaya baik oleh pemerintah daerah setempa maupun institusi yang berwenang. Kebijaka penataan kiranya mutlak diperlukan untuk memberikan kerangka legalisasi bagi situssitus ini sehingga memiliki payung hukum untuk perlindungan dan pelestariannya. $\mathrm{Ha}$ ketiga adalah menyangkut arah dan kebijakan penelitian ke depan untuk lingkup kawasa Halmahera bagian tengah. Mengacu surve awal yang telah dilakukan terlihat potens yang dimiliki oleh wilayah ini pengembangan cakupan penelitiar dilakukan dengan meluaskan geograf kawasan pengamatan lebih ke Halmaher Tengah bagian barat. Tinjauan ke kawasan interior ke arah utara Halmahera bagian tengah juga dapat dilakukan menimbang luasnya cakupan wilayah karst yang teramati dalan kawasan ini. Isu penelitian kiranya masih layak untuk dilekatkan dengan pertanyaan terkait okupasi awal manusia pada mas holosen dalam kaitan dengan proses migras penutur bahasa Austronesia. Cakupan is ini kiranya masih dapat diperluas dengan mengamati dinamika sosial dalam kawasan menjelang masuk ke masa sejarah khususnya peran wilayah ini menjelang era pembentukan lembaga-lembaga politik dalam kawasan sebagaimana diwakili oleh munculnya empa kerajaan besar di Maluku Utara.

\section{PENUTUP}

Survei arkeologis yang dilaksanakan di wilayah Halmahera Tengah merupakan inisiasi studi arkeologi oleh Balai Arkeologi Ambon di kawasan ini. Wilayah ini merupakan bagian dari geografi besar Pulau Halmahera yang memiliki peran penting dalam konstruksi sejarah budaya kawasan timur laut Nusantara termasuk dalam hubungan dengan pengetahuan arkeologi di Asia Tenggara dan Pasifik. Studi atas kawasan ini kiranya menjadi keharusan untuk mendapatkan pemahaman terkait dinamika budaya masa lalu wilayah ini dalam kaitan dengan kawasan sekitarnya. Penentuan lokus kajian di wilayah ini kiranya juga terkait dengan kondisi terkin menyangkut pembukaan kawasan kontrak karya pertambangan Nikel dan Kobalt oleh Weda Bay Nikel. Berlokasi di kawasan pesisir hingga pedalaman Halmahera Bagian Tengah, kawasan pertambangan ini berpotens mengancam kelestarian berbagai sumber daya arkeologis dan budaya yang berada dalam cakupan kontrak karya. Kegiatan pengamatan dilakukan meliputi wilayah-wilayah yang berpotensi terganggu tersebut serta area diluar kawasan kontrak karya namun dapa terganggu oleh aktivitas pertambangan.

$$
\text { Hasil penelitian mendata hampir }
$$

selusin titik pengamatan yang dipandang memiliki potensi tinggi secara arkeologis. Karakteristik setiap situs bervariasi mulai dari lingkungan gua, daerah aliran sungai, struktur megalitik, hingga jejak pemukiman kuna. Titik pengamatan yang dipandang paling potensial diwakili oleh situs Gua Yol dan Gua Sora 3. Hasil pengamatan di situs ini mendata temuan permukaan berupa fragmen gerabah, fragmen alat batu dan moluska yang mengindikasikan aktivitas hunian masa lalu. Studi lebih lanjut dan tindakan ekskavas kiranya perlu dilaksanakan untuk kedua situs ini.

Dalam kaitan dengan dampak aktivitas penambangan oleh Weda Bay Nikel, hampir seluruh situs yang teramati akan terke dampak langsung maupun tidak langsung. Wilayah kontrak karya penambangan yang sangat luas, juga meliputi sebagian besar titik-titik pengamatan baik situs-situs gua maupun lokus yang memiliki kaitan dengan sejarah lokal dan memori sosial bagi masyarakat setempat. Beberapa sumber menyebutkan pemitakatan warisan budaya telah dilaksanakan oleh pihak perusahaan, namun detil rencana penyelamatan dan pengelolaan situs-situs yang tercakup dalam wilayah kontrak karya hingga saat ini belum jelas. Komunikasi terkait arah pengelolaan segenap warisan budaya dalam lingkup wilayah kontrak karya kiranya menjadi hal yang mendesak menimbang nilai penting yang dimiliki oleh situs-situs ini bagi pengetahuan sejarah budaya Halmahera dan Maluku Utara.

\section{DAFTAR PUSTAKA}

Arifin, Karina dan Philippe Delanghue, Rock art in West Papua, Italia: UNESCO, 2004.

Ballard, C. 1988. Dudumahan: a rock art site on Kai Kecil, Southeast Mollucas. Bulletin of 8, Canberra: Australia National University pp. 139-161.

Bellwood, Peter. 2000. Prasejarah kepulauan Indo-Malaysia. Jakarta: PT. Gramedia.

Bulmer, S dan Bulmer, R. 1964. The prehistory of the Australian New Guinea Highlands the Central Highlands. American Anthropologist 66.4, Part 2 Special

Ellen, R. F dan Glover, I. C. Pottery Manufacture and Trade in the Central Moluccas, Indonesia: the Modern Situation and the
Historical Implications', dalam Man n.s 9: 353-379

Flannery, T. and White, P. 1991. Animal TransResearch and Exploration 7: 96-113

Gelpke, S. 1994. The report of Miguel Roxo de Brito of his voyage in $1581-2$ to Raja
Ampat, the MacCluer Gulf and Seram.
Bijdragen tot de Taal-, Land- en Volkenkunde 150: 123-145

Heinsohn, T.E. 2010. Marsupial as introduced species: Long -term anthropogenic eximplications for zoogeographic interpretation dalam Terra Austrialis 32: Altered Ecologies: Fire, climate and human influence on terrestrial landscapes. Canberra: ANU Press.

Jelsma, J. 1999. Room with a view: An excavation in Toe Cave, Ayamaru District, Bird's Quaternary Research in Southeast Asia 15:41-45.

Lape, P.V. 2000a. Contact and Conflict in the Banda Islands, Eastern Indonesia, 11th to Brown University, Rhode Island.

Lape, P.V. 2000b. Political dynamics and religious change in the late pre-colonial Banda Islands, Eastern Indonesia. World Archaeology 32(1). London: Routledge pp. $138-55$

Lape, P. 2006. Chronology of fortified sites in East Timor. In Journal of Island an
Coastal Archaeology 1. Pp 285-297

Lape, P. 2010. Paleoclimates and emergence of fortification in the tropical Pacific islands. Arcaheology Vol. 29 Issue 1. March 2010.

Lilley, I. 1992. Papua New Guinea's Human Past: the Evidence in Archaeology dalan R.D Attenborough dan M.P Alpers (eds.) Small Cosmos Oxford: Clarendea: the 150-171.

hmud, I. 2009. Pernak-pernik penelitian No.2. Jayapura: Balai Arkeologi Jayapura.

Miedema, J et. al .Perspectives on The Bird's Head of Irian Jaya, Indonesia, Proceedings of 1997. Amsterdam.: Rodopi B.V.

Pasveer, J.M. 1998. Kria cave: an 8000-year occupation sequence from Bird's Head of in Southeast Asia 15: 67-89

Prasetyo, Bagyo. 2009. Perkembangan hasi penelitian arkeologi di Tanah Papua. dalam Dinamika Kebangsaan dan 
Pembangunan, dalam rangka Semarak Arkeologi 2009, di Jayapura Papua, 3 - 4 Juni 2009.

Ririmasse, M. 2005. Jejak dan Prospek Penelitian Arkeologi di Maluku. Dalam Kapata Arkeologi Volume 1 No. 1. Ambon: Balai Arkeologi Ambon.

Ririmasse, M. 2007. Fragmen Moko dari Selaru: Temuan Baru Artefak Logam di Maluku. Dalam Berita Penelitian Arkeologi Volume 3 No. 5. Ambon: Balai Arkeologi Ambon.

Ririmasse, M. 2008. Visualisasi tema perahu dalam rekayasa situs arkeologi di Maluku. Dalam Naditira Widya Volume 2 No. 1. Banjarmasin: Balai Arkeologi Banjarmasin.

Ririmasse, M. 2010a. Boat Symbolism and Identity in the Insular Southeast Asia: A Case Study from the Southeast Moluccas. Tesis Pascasarjana. Tidak diterbitkan. Leiden: Rijkuniversiteit Leiden.

Ririmasse, M. 2010b. Arkeologi Pulau-Pulau Terdepan di Maluku: Sebuah Tinjauan Awal. Kapata Arkeologi Vol. 6 No. 10. Ambon: Balai Arkeologi Ambon.

Ririmasse, M. Koleksi Budaya Bendawi Maluku Tenggara di Museum Etnologi Nasional Leiden (dalam persiapan).

Sollewijn, Gelpke. 1994. The Report of Miguel Roxo de Brito of his Voyage in 1581-2 to the Raja Ampat, the MacCluer Gulf and Seram' in Bljdragen tot de Taal Land en Volkenkunde 150: 123-145.

Spriggs, M. 1997. The archaeology of the Bird's Head in it's Pacific and and Southease Asian context in

Spriggs, M. 1998. Research questions in Maluku archaeology. dalam Cakalele 9: 49-62.

Spriggs, M. \& D. Miller. 1988. A previously unreported bronze kettledrum from the Kai Islands, eastern Indonesia. IndoPacific Prehistory Association Bulletin 8. Canberra: Australia National University. pp.79-88.

Suroto, H.2010. Prasejarah Papua. Denpasar: Udayana University Press.

Tanudirdjo, D. 2001. Islands in Between: Prehistory of Northeastern Indonesia Archipelago. Unpublished PhD Thesis. Canberra: Australian National University.

Tanudirdjo, D. 2005. The dispersal of Austronesianspeaking people and the ethnogenesis of Indonesian people. In Austronesian Diaspora and the Ethnogeneses of People in Indonesian Achipelago. Jakarta: LIPI Press

Tanudirdjo, D. 2009. Interaksi Austronesia Melanesia: Kajian Interpretasi Teoritis. Makalah disampaikan Seminar Perspektif Budaya Melanesia dan Austronesia dalam Dinamika Kebangsaan dan Pembangunan, dalam rangka Semarak Arkeologi 2009, di Jayapura Papua, 3 - 4 Juni 2009.

O'Connor, S., Spriggs, M. Veth, P. 2005. The Aru Island in Perspective dalam O'Connor, Sue et.al. The Archaeology of the Aru Island. Canberra: Pandanus Books.

www. wikipedia.org. Link: http://fr.wikipedia. org/wiki/Weda (Diakses tanggal 5 Januari 2012).

www.google.co.id Link: https://www.google. co.id $/ \mathrm{maps} /$ preview?oe $=$ utf- $8 \&$ client $=$ firefox-a\&channel=sb\&q=pulau + halm ahera \&ie $=$ UTF $-8 \&$ hq $=\&$ hnear $=0 \times 329$ c4355071b2255:0x29b7aab208bfe27d, Halmahera\&gl=id\&ei=BPLyU5XQNtih ugTyrYGgBg\&ved=0CIMBEPIBMBA (Diakses tanggal 5 Januari 2012)

www.volcano.oregonstate.edu Link: http:// volcano.oregonstate.edu/oldroot/ volcanoes/volc images/southeast asia/ indonesia/group.html (Diakses tanggal 5 Januari 2012)

www.wedabaynickel.com Link: http://www. wedabaynickel.com/id/proyek-kelasdunia (Diakses tanggal 5 Januari 2012) 